\title{
AB-QTL analysis in spring barley: III. Identification of exotic alleles for the improvement of malting quality in spring barley (H. vulgare ssp. spontaneum)
}

\author{
Maria von Korff · Huajun Wang · Jens Léon • \\ Klaus Pillen
}

Received: 21 August 2006/Accepted: 27 May 2007/Published online: 24 June 2007

(C) Springer Science+Business Media B.V. 2007

\begin{abstract}
Malting quality is genetically determined by the complex interaction of numerous traits which are expressed prior to and, in particular, during the malting process. Here, we applied the advanced backcross quantitative trait locus (AB-QTL) strategy (Tanksley and Nelson, Theor Appl Genet 92:191203, 1996), to detect QTLs for malting quality traits and, in addition, to identify favourable exotic alleles for the improvement of malting quality. For this, the $\mathrm{BC}_{2} \mathrm{DH}$ population $\mathrm{S} 42$ was generated from a cross between the spring barley cultivar Scarlett and the wild barley accession ISR42-8 (Hordeum vulgare
\end{abstract}

M. von Korff · H. Wang · J. Léon · K. Pillen Institute of Crop Science and Resource Conservation, University of Bonn, Katzenburgweg 5, 53115 Bonn, Germany

Present Address:

M. von Korff

International Center for Agricultural Research in the Dry

Areas (ICARDA), P.O. Box 5466, Aleppo, Syria

Present Address:

H. Wang

Gansu Key Lab of Crop Improvement \& Germplasm

Enhancement, Gansu Agricultural University,

Yingmencun 1, Anningqu district, Lanzhou 730070,

China

K. Pillen ( $\square)$

Max-Planck-Institute for Plant Breeding Research, Barley Genetics Research Group, Carl-von-Linné-Weg 10, 50829

Koln, Germany

e-mail: pillen@mpiz-koeln.mpg.de ssp. spontaneum). A QTL analysis in S42 for seven malting parameters measured in two different environments yielded 48 QTLs. The exotic genotype improved the trait performance at $18(37.5 \%)$ of 48 QTLs. These favourable exotic alleles were detected, in particular, on the chromosome arms $3 \mathrm{HL}$, 4HS, 4HL and 6HL. The exotic allele on 4HL, for example, improved $\alpha$-amylase activity by $16.3 \%$, fermentability by $0.8 \%$ and reduced raw protein by $2.4 \%$. On chromosome 6HL, the exotic allele increased $\alpha$ amylase by $16.0 \%$, fermentability by $1.3 \%$, friability by $7.3 \%$ and reduced viscosity by $2.9 \%$. Favourable transgressive segregation, i.e. S42 lines exhibiting significantly better performance than the recurrent parent Scarlett, was recorded for four traits. For $\alpha$ amylase, fermentability, fine-grind extract and VZ45 20, 16, 2 and 26 S42 lines, respectively, surpassed the recurrent parent Scarlett. The present study hence demonstrates that wild barley does harbour valuable alleles, which can enrich the genetic basis of cultivated barley and improve malting quality traits.

Keywords Hordeum vulgare ssp. spontaneum . Barley $\cdot$ SSR $\cdot$ AB-QTL $\cdot$ Malting

\section{Introduction}

The improvement of malting quality ranges among the most important breeding goals in spring barley. Malting quality is determined by the complex 
interaction of several traits expressed during grain development, germination and the malting process. The development of molecular markers and genetic linkage maps has allowed to identify and map quantitative trait loci (QTL) for malting quality in a number of different crosses (Hayes et al. 1993, 2003; Han et al. 1995, 1997, 2004; Mather et al. 1997; Thomas et al. 1996; Marquez-Cedillo et al. 2000, Zale et al. 2000, Barr et al. 2003a, b; Fox et al. 2003; Karakousis et al. 2003; Read et al. 2003; Gao et al. 2004). So far, breeders and scientists have primarily targeted elite germplasm from different geographic regions to improve and analyse malting quality traits in barley. Modern plant breeding, however, has reduced the genetic variability among domesticated barley cultivars (Forster et al. 1997; Baek et al. 2003). In the wake of this development, the exploitation of natural variation in exotic germplasm for the improvement of cultivars has received increasing attention. Ahokas and Naskali (1990a, b) could show that $H$. spontaneum accessions from Israel and Jordan exhibit a wide variation for malting quality traits, such as $\alpha$ - and $\beta$-amylase, $\beta$-glucanase, and other hydrolases. Nevertheless, only few studies have attempted to use wild barley to improve malting quality, and these have primarily focused on single genes. Investigation of natural variation in the $\beta$ amylase gene Bmyl, for example, led to the identification of a new haplotype in wild barley encoding for a $\beta$-amylase isoform with increased thermostability (Eglington et al. 1998; Erkkilä et al. 1998). Only two QTL studies involving exotic germplasm have so far been conducted for malting quality (Pillen et al. 2003; Li et al. 2005). Pillen et al. (2003) analysed protein content, friability and water absorption in a cross between the feed barley Apex and the wild barley accession ISR101-23, and Li et al. (2005) examined protein content, malt extract and friability in the population Brenda/HS213. Although Pillen et al. (2003) and Li et al. (2005) reported that most exotic alleles had a negative influence on malting performance, a few exotic alleles clearly improved the analysed trait. These findings together with the large genetic diversity identified in wild barley, encourage further studies of the effect of exotic alleles on malting quality.

Therefore the aim of the present study was to detect favourable exotic alleles for malting quality using the AB-QTL strategy (Advanced backcross
QTL) as proposed by Tanksley and Nelson (1996). The AB-QTL analysis was conducted with the $\mathrm{BC}_{2} \mathrm{DH}$ population $\mathrm{S} 42$ derived from the cross of the malting barley cultivar Scarlett, a high quality malting variety, with the wild barley accession ISR42-8 from Israel. Favourable effects of the exotic donor accession ISR42-8 on disease resistances and agronomic traits have already been reported by von Korff et al. (2005, 2006).

\section{Materials and methods}

\section{Plant material}

The development of the population S42 with 301 $\mathrm{BC}_{2} \mathrm{DH}$ lines originating from the cross of the German spring barley variety Scarlett, made from the cross Amazone $\times$ St. $2730 \mathrm{e} \times \mathrm{Kym}$ at Saatzucht Breun, with the Israeli wild barley accession ISR42-8 is described in detail in von Korff et al. (2004). The $\mathrm{BC}_{2} \mathrm{DH}$ lines are derived from $12 \mathrm{BC}_{1}$ families with a mean number of progenies per $\mathrm{BC}_{1}$-family of 25.1 $(\mathrm{STD}=19.1)$ and from $76 \mathrm{BC}_{2}$-families with a mean of 4 lines $\left(\mathrm{STD}=5.8\right.$ ) per $\mathrm{BC}_{2}$-family.

\section{Molecular characterisation}

The $\mathrm{BC}_{2} \mathrm{DH}$ population was genotyped with $98 \mathrm{SSR}$ markers as described in von Korff et al. (2004).

Cultivation of the DH-population

The population S42 was grown at four different locations and in the two consecutive years 2003, 2004 to investigate agronomic performance (von Korff et al. 2006). Due to the high costs of micromalting, samples from only two different locations could be selected for the analysis of malting quality. The selected test locations were the Dikopshof Research Station (D03, University of Bonn, West Germany), and the experimental station of the breeding company Nordsaat Saatzucht (G03, Gudow, North Germany). The field experiment was designed in randomised plots without replications. As a control, the recurrent parent Scarlett was tested with 20 replications per test location. Net plot sizes were 6.0 (D03) and $8.0 \mathrm{~m}^{2}$ (G03). Nitrogen fertilization was $60 \mathrm{~kg} \mathrm{~N}^{-1}$ in D03 and $40 \mathrm{~kg} \mathrm{~N} \mathrm{ha}^{-1}$ in G03 taking into account the 
$\mathrm{N}_{\min }$ content in the soil. Sowing with 300 (D03) and 330 (G03) kernels $/ \mathrm{m}^{2}$, and the application of growth regulators (D03, G03) and fungicides (D03, G03) were in accordance with local practices. The grain was harvested with a plot harvester at maturity, and the cleaned grain samples were stored at $4{ }^{\circ} \mathrm{C}$ before analysis.

\section{Malting quality analysis}

Micromalting was performed in the laboratory of the Nordsaat Saatzucht (Böhnshausen, Germany) with $100 \mathrm{~g}$ of grain of a sieving fraction of $>2.5 \mathrm{~mm}$. The malting process consisted of the following program. Steeping comprised of 2 cycles of $8 \mathrm{~h} \mathrm{immersion}$ and $16 \mathrm{~h}$ air-rest both at $14^{\circ} \mathrm{C}$. Ex-steep moisture was targeted to reach $45.5 \%$ for all the samples. Since the water absorption rate was variable among samples, samples with less than $45.5 \%$ moisture were further steeped to reach the desired moisture. Samples were germinated at $14^{\circ} \mathrm{C}$ and $95 \%$ air humidity for 5 days. Kilning was carried out for $16 \mathrm{~h}$ at $80^{\circ} \mathrm{C}$. Rootlets were mechanically removed prior to analysis. Raw protein was measured from $20 \mathrm{~g}$ of ground sample using NIR (NIRSystems 5000, FOSS GmbH, Hamburg). $\alpha$-amylase activity was determined as dextrination time of a standardized starch solution in the presence of excess ß-amylase (EBC, European Brewing Convention).

The remaining quality characters, fermentability (= final attenuation), fine-grind extract, friability, viscosity and Hartong $45^{\circ} \mathrm{C}$ (VZ45), were determined using the methods recommended by the EBC (European Brewing Convention) or the MEBAK (Mitteleuropäische Brautechnische Analysenkommission) as listed in Table 1.

\section{Statistical analyses}

Statistical analyses were carried out with SAS version 9.1 (SAS Institute 2003). Genetic correlations between trait values were calculated with the least square means of $\mathrm{BC}_{2} \mathrm{DH}$ lines averaged across both environments. Significant favourable transgression of S42 lines, where the trait value is improved compared to the recurrent parent Scarlett, was accepted when the least square means of a $\mathrm{BC}_{2} \mathrm{DH}$ line surpassed the least square means of the control Scarlett by more than two standard deviations.

The detection of QTLs was carried out using the following mixed hierarchical model in the SAS general linear model (GLM) procedure:

$$
\begin{aligned}
\mathrm{Y}_{\mathrm{ijkmn}}= & \mu+\mathrm{M}_{\mathrm{i}}+\mathrm{BC} 1_{\mathrm{j}}+\mathrm{BC} 2_{\mathrm{k}}\left(\mathrm{BC} 1_{\mathrm{j}}\right)+\mathrm{E}_{\mathrm{m}} \\
& +\mathrm{M}_{\mathrm{i}}{ }^{*} \mathrm{E}_{\mathrm{m}}+\mathrm{RP}+\text { Hea }+\varepsilon_{\mathrm{n}(\mathrm{jikm}),}
\end{aligned}
$$

where $\mu$ is the general mean, $\mathbf{M}_{\mathrm{i}}$ is the fixed effect of the $\mathrm{i}$-th marker genotype, $\mathrm{BC} 1_{j}$ is the random effect of the $\mathrm{j}$-th $\mathrm{BC}_{1}$-family, $\mathrm{BC} 2_{\mathrm{k}}\left(\mathrm{BC} 1_{\mathrm{j}}\right)$ is the random effect of the $\mathrm{k}$-th $\mathrm{BC}_{2}$-family nested in the $\mathrm{j}$ th $\mathrm{BC}_{1}$-family, $\mathrm{E}_{\mathrm{m}}$ is the random effect of the $\mathrm{m}$-th environment, $M_{i} * E_{m}$ is the random interaction effect of the i-th marker genotype with the m-th environment, $\varepsilon_{\mathrm{n}(\mathrm{jikm})}$ is the error of $\mathrm{Y}_{\mathrm{ijkmn}}$. Two co-variates, protein content (RP) and heading date (Hea) were added to the model, as protein content and developmental stage have been shown to affect malting quality parameters. Marker main effects with an FDR of 0.05 (false discovery rate, Benjamini and Yekutieli 2005) were interpreted as putative QTLs. Linked significant markers with a distance of $\leq 20 \mathrm{cM}$ and showing the same effect were interpreted as a single putative QTL, and only the marker with the highest $F$-value from each group of linked loci is recorded. The relative performance of the homozygous exotic genotype (RP $[H s p])$ were calculated as described in von Korff et al. (2005). The genetic variance explained by a marker $\left(\mathrm{R}_{\mathrm{M}}^{2}\right)$ was calculated as follows:

$\mathrm{R}_{\mathrm{M}}^{2}=\mathrm{SQ}_{\mathrm{M}} / \mathrm{SQ}_{\mathrm{G}}$

$\mathrm{SQ}_{\mathrm{M}}$ corresponds to the sum of squares of $\mathrm{M}$. $\mathrm{SQ}_{\mathrm{G}}$ was calculated as the sums of squares of the $\mathrm{BC}_{2} \mathrm{DH}$ lines in the following ANOVA model:

$\mathrm{Y}_{\mathrm{ijkm}}=\mu+\mathrm{L}_{\mathrm{i}}+\mathrm{BC} 1_{\mathrm{j}}+\mathrm{BC} 2_{\mathrm{k}}\left(\mathrm{BC} 1_{\mathrm{j}}\right)+\mathrm{E}_{\mathrm{m}}+\varepsilon_{\mathrm{m}(\mathrm{jik})}$,

where $L_{i}$ is the fixed effect of the $i-t h B_{2} D H$ line, $B C 1_{j}$ is the random effect of the $\mathrm{j}$-th $\mathrm{BC}_{1}$-family, $B C 2_{k}\left(B C 1_{j}\right)$ is the random effect of the k-th $\mathrm{BC}_{2^{-}}$ family nested in the $\mathrm{j}$-th $\mathrm{BC}_{1}$-family and $\mathrm{E}_{\mathrm{m}}$ is the random effect of the $\mathrm{m}$-th environment. $\mathrm{SQ}_{\mathrm{G}}$ was calculated for every marker separately to account for the occurrence of missing genotype data. 
Table 1 Least square means, standard deviations and number of favourable transgressive lines for seven malting traits calculated across two environments for the population S42 and the recurrent parent Scarlett

\begin{tabular}{|c|c|c|c|c|c|c|c|}
\hline \multirow[t]{2}{*}{ Abbr } & \multirow[t]{2}{*}{ Trait } & \multirow[t]{2}{*}{ Reference $^{\mathrm{a}}$} & \multicolumn{2}{|c|}{ Lsmeans ${ }^{\mathrm{b}}$} & \multicolumn{2}{|c|}{ Standard deviation $^{\mathrm{c}}$} & \multirow{2}{*}{$\begin{array}{l}\text { Number of transgressive } \\
\text { S42 lines }\end{array}$} \\
\hline & & & $\mathrm{S} 42$ & Scarlett & $\mathrm{S} 42$ & Scarlett & \\
\hline AA & $\alpha$-amylase activity of malt & EBC 4.13 & 341.5 & $377.3^{*}$ & 86.8 & 35.7 & $20(6.6 \%)$ \\
\hline FER & Fermentability of wort (= Final attenuation) & EBC 4.11 .2 & 85.1 & 85.2 & 2.6 & 1.5 & $16(5.3 \%)$ \\
\hline FGE & Fine-grind extract of malt & EBC 4.5.1 & 82.4 & $84.7 * *$ & 2.2 & 0.8 & $2(0.7 \%)$ \\
\hline FRI & Friability of malt & EBC 4.15 & 74.1 & $89.7 * *$ & 12.5 & 4.8 & 0 \\
\hline PRO & Grain protein content & EBC 3.3 .1 & 10.1 & $9.1 * *$ & 1.0 & 0.4 & 0 \\
\hline VIS & Viscosity of wort & EBC 4.8 & 1.6 & $1.5 * *$ & 0.1 & 0.05 & 0 \\
\hline VZ45 & Hartong $45^{\circ} \mathrm{C}$, extract at $45^{\circ} \mathrm{C}$ & MEBAK & 42.6 & $44.7 *$ & 6.3 & 2.5 & $26(8.6 \%)$ \\
\hline
\end{tabular}

a EBC: European Brewery convention (2005), MEBAK, Mitteleuropäische Brautechnische Analysenkommission (1997)

b Significant differences of least square means were tested with $* P<0.05$ and $* * P<0.01$

c Calculation of standard deviation of Scarlett was based on 20 replicates per environment (D03 and G03)

d Definition of favourable transgression: see materials and methods

\section{Results}

Comparison of the population S42 with the recurrent parent

In order to compare the performance of the $\mathrm{BC}_{2} \mathrm{DH}$ population with that of the recurrent parent, the least square means of all traits for the population S42 and Scarlett were calculated (Table 1). The comparison of S42 and Scarlett revealed significant differences for the traits $\alpha$-amylase, fine-grind extract, friability and VZ45, where the mean performance of S42 was below that of the recurrent parent. For protein content and viscosity the mean trait values of the population S42 were significantly above those of Scarlett.

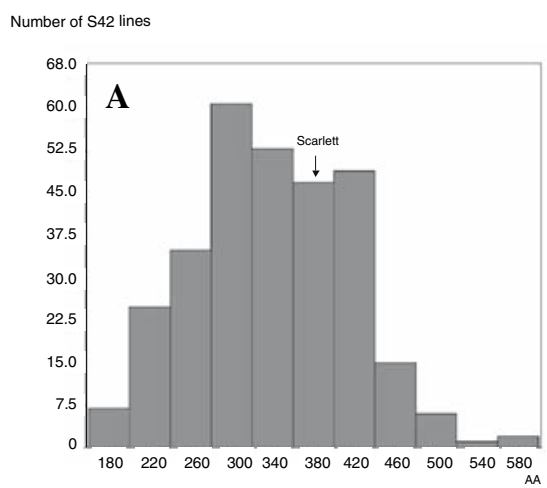

Based on extreme values of the S42 progeny, favourable transgressive segregation, i.e. S42 lines exhibiting significant better performance than Scarlett, was recorded for four traits (Table 1). Favourable transgression was detected for the traits $\alpha$-amylase with 20 S42 lines, fermentability with 16 S42 lines, fine-grind extract with 2 S42 lines and VZ45 with 26 S42 lines which surpassed the least square means of the recurrent parent Scarlett by more than two standard deviations (Table 1, Fig. 1).

Correlations

A total of 31 significant correlations were detected between seven malting traits, heading date and the

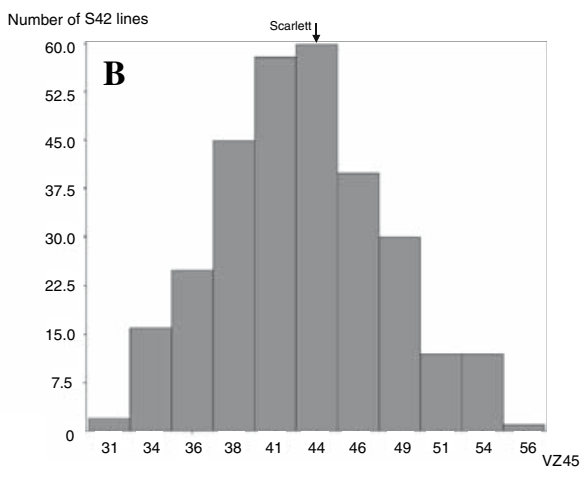

Fig. 1 Phenotypic distribution of the traits $\alpha$-amylase (A) and VZ45 (B) in population S42. The distribution was calculated with least square means averaged across the two environments. Least square means and standard deviations are given in Table 1 
percentage of exotic genome per line $(\mathrm{P}[H s p]$, see Table 2). Higher correlations above 0.50 are as follows: $\alpha$-amylase showed positive correlations with fermentability, friability and VZ45 of $0.55,0.48$ and 0.52 , respectively, and a negative correlation of -0.59 with viscosity. In addition, fine-grind extract exhibited positive correlations with friability and VZ45 of 0.67 and 0.58 , and negative correlations with raw protein and viscosity of -0.77 and -0.54 , respectively. Finally, friability revealed negative correlations of -0.63 and -0.82 with protein and viscosity, respectively. In order to analyse the impact of developmental differences on malting quality, correlations between heading date (von Korff et al. 2006) and malting parameters were calculated. The parameters measuring enzyme activity, $\alpha$-amylase and VZ45, showed no or low correlations with heading date. Heading date, however, was negatively correlated with protein content $(-0.56)$, viscosity $(-0.45)$ and positively correlated with fine-grind extract $(0.46)$ and friability (0.64). In order to test the hypothesis that a high percentage of exotic germplasm $\mathrm{P}[\mathrm{Hsp}]$ has a negative influence on malting quality, the proportion of exotic alleles in a $\mathrm{BC}_{2} \mathrm{DH}$ lines was calculated. $\mathrm{P}[H s p]$ revealed negative correlations with fine-grind extract and friability of -0.49 and -0.50 , respectively, and positive correlations with protein content and viscosity of 0.28 and 0.47 , respectively.

QTL analysis

The ANOVA revealed 103 significant marker trait associations. Due to linkage between markers, these effects were summarised to 48 putative QTLs for seven malting parameters (Table 3, Fig. 2). The exotic genotype improved the trait performance at 18 (37.5\%) of 48 QTLs. In the following, the QTLs are presented for each trait separately.

$\alpha$-amylase (AA)

For $\alpha$-amylase, the analysis revealed eight QTLs on five chromosomes. The exotic alleles increased AA activity at four QTLs by a maximum of $16.3 \%$ at QAa.S42-4H.c. The latter QTL showed with $12.6 \%$ the strongest effect on the genetic variance. At four QTLs the exotic allele caused a decrease in enzyme activity by maximal $21.5 \%$ at QAa.S42-5H.b.

Fermentability (FER)

Three QTLs were detected for fermentability on chromosomes $4 \mathrm{H}$ and $6 \mathrm{H}$. The exotic allele increased the trait value at all three QTLs by a maximum of $1.5 \%$ on the short arm of chromosome $4 \mathrm{H}$. The maximum genetic variance was explained at QFer.S42-6H.a with 2.9\%.

Fine-grind extract (FGE)

For fine-grind extract, altogether four QTLs were identified on the chromosomes $1 \mathrm{H}, 3 \mathrm{H}$ and $7 \mathrm{H}$. Finegrind extract was increased by the exotic allele at QFge.S42-3H.a. The exotic allele decreased finegrind extract at three loci by a maximum of $2.2 \%$ at QFge.S42-1H.b. This locus explained $10.7 \%$ of genetic variance.

Table 2 Pearson correlation coefficients $(r)$ between seven malting traits, heading date and the percentage of exotic genome per line $(\mathrm{P}[H s p])$

\begin{tabular}{|c|c|c|c|c|c|c|c|c|}
\hline & FER & FGE & FRI & PRO & VIS & VZ45 & HEA & $\mathrm{P}[H s p]$ \\
\hline AA & $0.55 * * *$ & $0.25 * * *$ & $0.48 * * *$ & $-0.14 *$ & $-0.59 * * *$ & $0.52 * * *$ & -0.09 n.s. & $-0.16^{*}$ \\
\hline FER & & $0.13 *$ & $0.49 * * *$ & $-0.21 * * *$ & $-0.49 * * *$ & 0.07 n.s. & 0.04 n.s. & $-0.12 *$ \\
\hline FGE & & & $0.67 * * *$ & $-0.77 * * *$ & $-0.54 * * *$ & $0.58 * * *$ & $0.46 * * *$ & $-0.49 * * *$ \\
\hline FRI & & & & $-0.63 * * *$ & $-0.82 * * *$ & $0.33 * * *$ & $0.64 * * *$ & $-0.50 * * *$ \\
\hline PRO & & & & & $0.42 * * *$ & $-0.27 * * *$ & $-0.56 * * *$ & $0.28 * * *$ \\
\hline VIS & & & & & & $-0.46 * * *$ & $-0.45^{* * *}$ & $0.47 * * *$ \\
\hline VZ45 & & & & & & & -0.04 n.s. & $-0.25 * * *$ \\
\hline
\end{tabular}

For calculating correlations, the least square means of the trait performance of each $\mathrm{BC}_{2} \mathrm{DH}$ line averaged across environments were used. The significance thresholds for $r$ values are $* P<0.05$, $* * P<0.01$, $* * * P<0.001$, n.s. not significant. $\mathrm{P}[H s p]$ is the percentage of exotic genome per S42 line calculated according to von Korff et al. (2004). Heading date was analysed as reported in von Korff et al. (2006) 


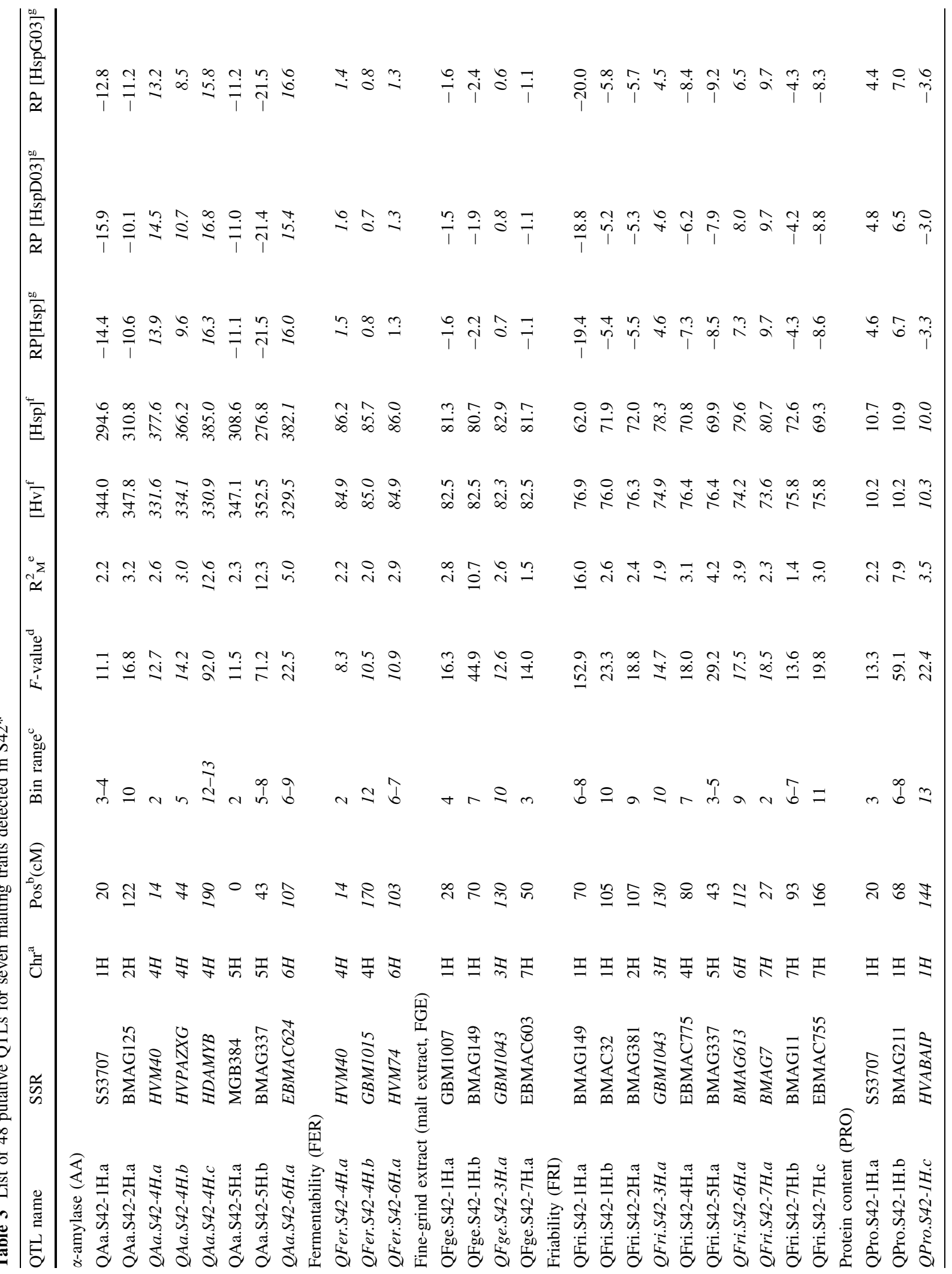




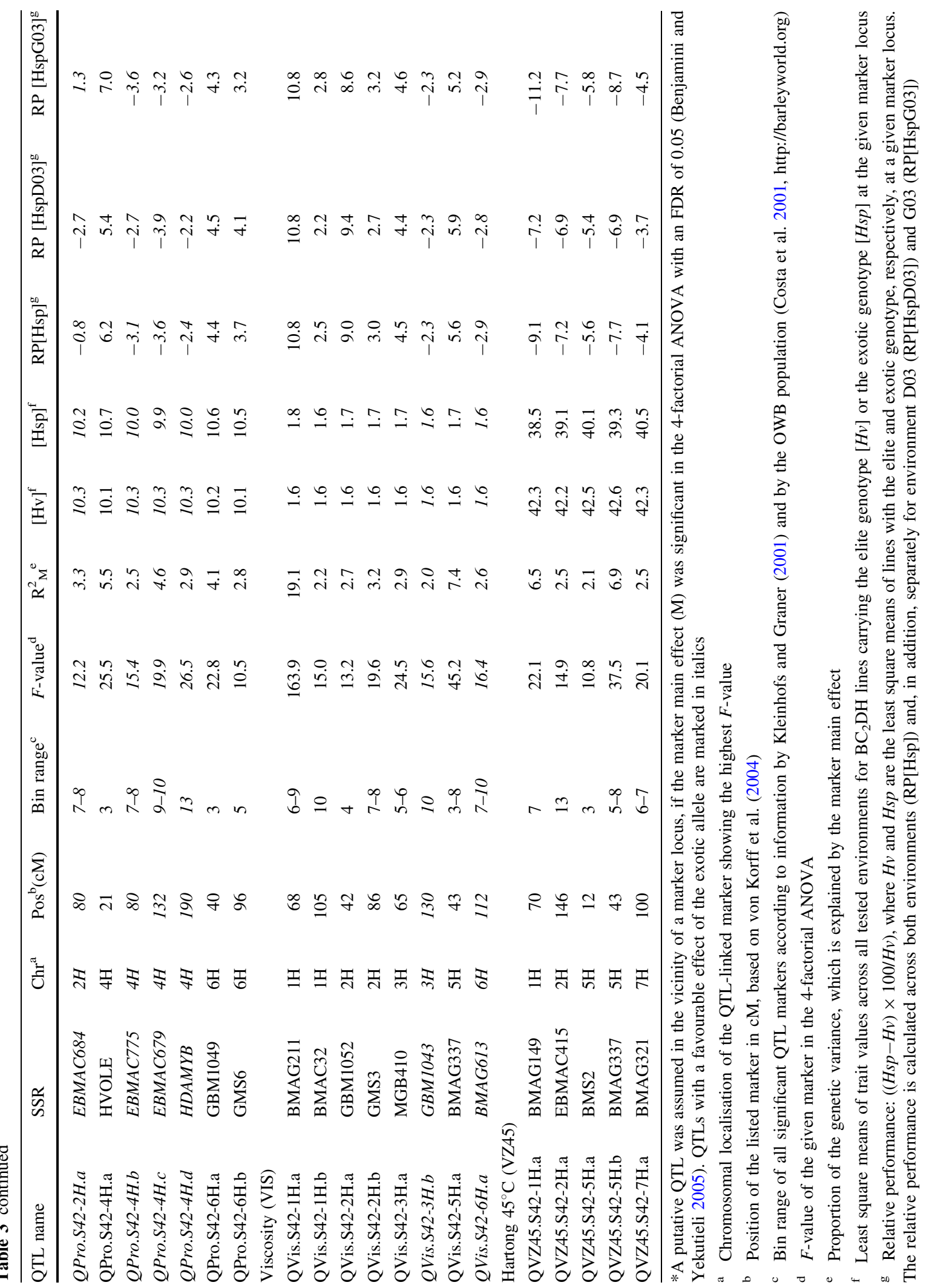


Friability (FRI)

Ten QTLs were identified for friability on all seven chromosomes. The exotic allele improved friability at three QTLs by a maximum of 9.7\% at QFri.S42-7H.a. At seven QTLs the exotic allele decreased friability by maximal $19.4 \%$ at QFri.S42-1H.a. This locus explained $16.0 \%$ of the genetic variance.

\section{Protein content (PRO)}

For protein content, ten QTLs were detected on chromosomes $1 \mathrm{H}, 2 \mathrm{H}, 4 \mathrm{H}$ and $6 \mathrm{H}$. The exotic genotype reduced protein content at five QTLs by a maximum of 3.6\% at QPro.S42-4Hc. At five loci the exotic allele increased PRO where the strongest effect was measured at QPro.S42-1H.b, which explained $7.9 \%$ of the genetic variance and increased PRO by on average $6.7 \%$.

\section{Viscosity (VIS)}

Eight QTLs were found for viscosity on chromosomes $1 \mathrm{H}, 2 \mathrm{H}, 3 \mathrm{H}, 5 \mathrm{H}$ and $6 \mathrm{H}$. The exotic allele decreased viscosity at two QTLs by maximal $2.9 \%$ at QVis.S42-6H.a. At six loci the exotic genotype increased VIS by a maximum of $10.8 \%$ at QVis.S42-1H.a. This locus explained $19.1 \%$ of the genetic variance.

\section{Hartong $45^{\circ} \mathrm{C}(\mathrm{VZ} 45)$}

For VZ45, five QTLs were discovered on chromosomes $1 \mathrm{H}, 2 \mathrm{H}, 5 \mathrm{H}$ and $7 \mathrm{H}$. At all loci the exotic allele decreased VZ45 by up to $9.1 \%$ at QVZ45.S42-1H.a. The maximum genetic variance was explained at QVZ45.S42-5H.b with 6.9\%.

\section{Discussion}

Malting quality is often viewed as one of the most complex and sensitive traits, which needs fine-tuning of a high number of interacting genes over many decades of selection. Breeding for malting quality has therefore concentrated on a restricted gene pool with high malting quality donors and avoided the use of exotic germplasm. The present study, however, indicated, that wild barley does harbour genes which have the potential to improve malting quality parameters. The exotic donor improved malting quality at $37.5 \%$ of all QTLs. Only for VZ45 no favourable exotic alleles could be detected. Most favourable exotic alleles were found for improved protein content (5) and $\alpha$-amylase (4). It has been shown that wild barley harbours a wealth of diverse alleles for resistance against abiotic stresses, e.g. for drought tolerance (Grando and Ceccarelli 1995), and for cold tolerance (Crosatti et al. 1996). Consequently, the exotic alleles may be a source for $\alpha$-amylases with increased activity, possibly due to better thermostability. Indeed, a more thermostable $\beta$-amylase form of the Bmyl gene has already been identified in wild barley (Erkkilä et al. 1998; Paris et al. 2002). Sequencing of the Bmyl locus in ISR42-8 revealed the Bmy1-Sd3 allele which is associated with increased $\beta$-amylase thermostability (data not shown).

Figure 2 shows that some genomic regions, in particular on $1 \mathrm{H}$ and $5 \mathrm{H}$, affected several different malting quality traits and simultaneously, showing the strongest effects on the genetic variance. The interspecific cross showed a wide variation for protein content and heading date (von Korff et al. 2006) and these traits are known to affect malting quality parameters. Consequently, these two characteristics were added as covariates to the analysis model, to exclude confounding effects of protein content and development on the malting quality parameters. Transgressive lines surpassing the recurrent parent Scarlett were detected for four malting parameters (Table 1). After validation of the superior performance in further field testings, these lines will be promising candidates for introgression of favourable alleles into elite material. In the following the studied traits will be discussed.

$\alpha$-amylase and fermentability

$\alpha$-amylase and fermentability showed a correlation of 0.55 (Table 2) and the three QTLs for fermentability coincided with QTLs for $\alpha$-amylase. Indeed, Evans et al. (2005) demonstrated that fermentability is primarily determined by the level and thermostability of $\alpha$ - and $\beta$-amylase and limit dextrinase. The exotic allele increased $\alpha$-amylase activity by $13.9 \%$ at QAa.S42-4H.a, by $16.3 \%$ at QAa.S42-4H.c and by $16.0 \%$ at QAa.S42-6H.a At these loci the exotic allele 

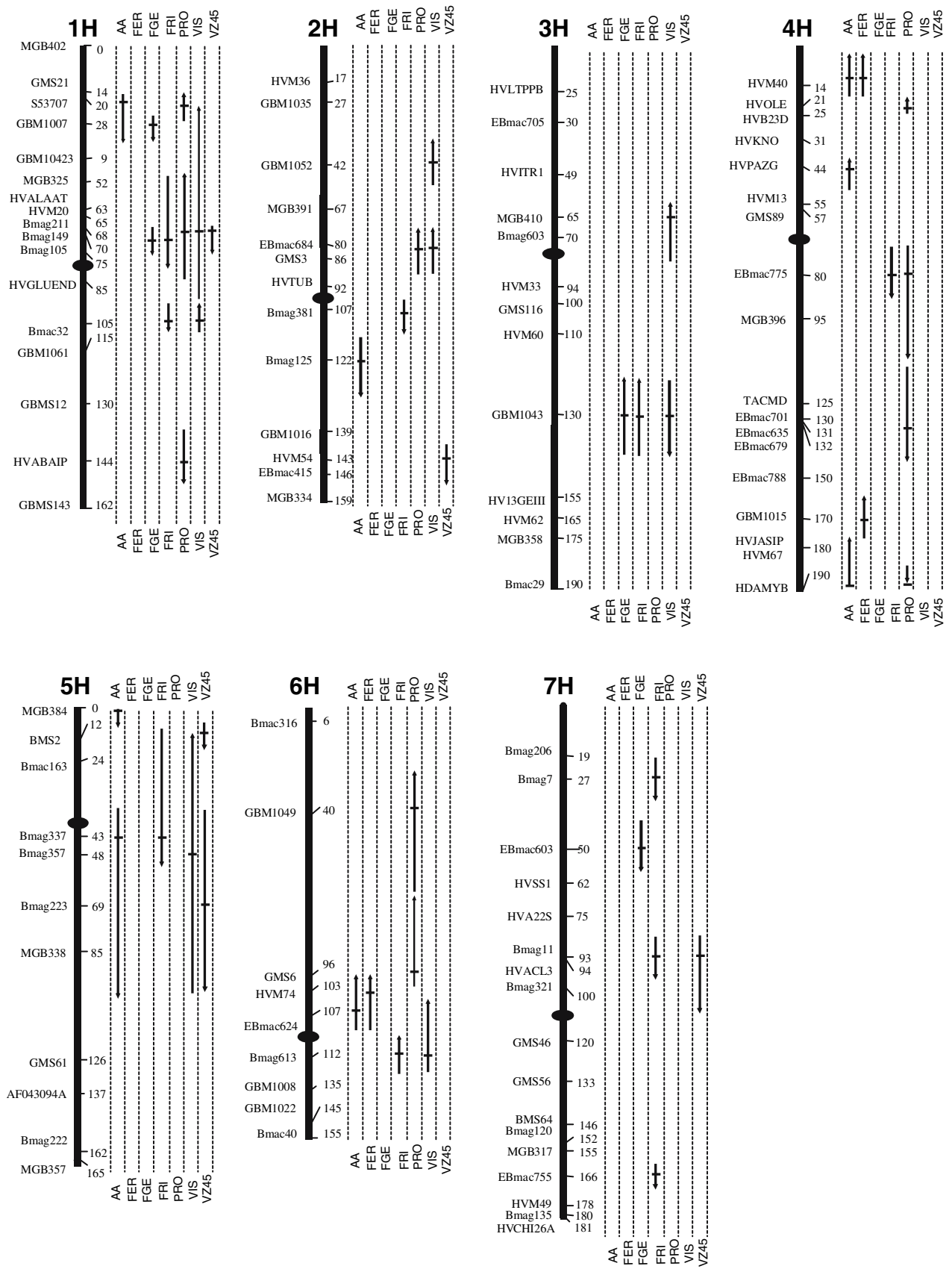

Fig. 2 QTL map of the population S42 containing 48 putative QTLs detected for seven malting traits. QTLs are indicated by black arrows along the chromosomes. Linked significant markers $(\leq 20 \mathrm{cM})$ showing the same effect are interpreted as one QTL extending from the half-intervals flanking the first

also improved fermentability. Improved fermentability of lines carrying the exotic genotype at these QTLs may thus be caused by increased $\alpha$-amylase activity. At QAa.S42-4H.c the exotic allele had also

and the last marker in that linkage group. The horizontal dashes in the arrows indicate the marker with the highest $F$-value in the ANOVA. The direction of the arrows indicates the $H s p$ effect: upward, the $H s p$ allele is increasing the trait value, downward; the Hsp allele is decreasing the trait value

favourable effects on protein level. This region of the chromosome $4 \mathrm{H}$ corresponds to the map position of $B m y l$, coding for $\beta$-amylase. The favourable effect on several malting parameters could be due to a 
pleiotropic effect of a single gene $(B m y l)$ on $\alpha-$ amylase and fermentability as the traits are biochemically correlated. The Bmyl gene, however, has also been associated with QTLs for height, flowering time and yield in S42 (von Korff et al. 2006) and is tightly linked to a major vernalisation gene, $\mathrm{Vrn}-\mathrm{H} 2$ (Laurie et al. 1995). Therefore, the association of Bmyl with malting parameters in wild barley may be due to linkage with variation at the $\mathrm{Vrn}-\mathrm{H} 2$ locus. However, as the analysis model included heading data as a covariate, the QTL-effect for AA and FER may also be independent of the $\mathrm{Vrn}-\mathrm{H} 2$ locus. Alternatively, the measurement of $\alpha$-amylase may have been confounded with $\beta$-amylase activity. With a suboptimal amount or activity of $\beta$-amylase added to the $\alpha$ amylase assay (as stated in the EBC 4.13 section 5.2) the amount of dextrinized soluble starch may have been limited not only by $\alpha$-amylase activity alone but also $\beta$-amylase activity in the sample.

There are two known forms of $\alpha$-amylase encoded by the Amyl locus on chromosome $6 \mathrm{H}$, bin 9, and the Amy 2 locus on chromosome 7H, bin 7 (Kleinhofs and Graner 2001). Significant $\alpha$-amylase QTLs have been located at the Amyl locus in two QTL studies involving the populations Harrington/TR306 and Chebec/Harrington (Mather et al. 1997; MarquezCedillo et al. 2000). In this study, the QTL QAa.S426H.a mapped close to the Amyl locus. At this locus the exotic allele encoded an enzyme with higher activity than the elite allele. Han et al. (1997) mapped QTLs with effects on diastatic power, $\alpha$-amylase, malt extract and $\beta$-glucan to the interval Brz-Amy 2 in the Steptoe/Morex population. However, no significant effect for $\alpha$-amylase was detected at the Amy2 locus in this study.

QAa.S42-5H.b explained $12.3 \%$ of the genetic variance, and the exotic allele reduced enzyme activity by $21.5 \%$. Significant QTLs for $\alpha$-amylase activity have been detected in the vicinity of this locus in several mapping populations by Coventry et al. (2003). The locus revealed pleiotropic effects on friability, viscosity and VZ45 in this study and has been associated with various malting parameters in previous studies (Zale et al. 2000). A number of stress related genes have been mapped to the same region on chromosome 5H, including Dhn1/Dhn2 (Choi et al. 2000), Vrnl (Laurie et al. 1995), the Cbf3 gene, a putative regulator of cold and drought response (Choi et al. 2002), and a gene encoding low molecular weight heat shock proteins (Maestri et al. 2002). These genes may also play a role in preserving enzyme activity at elevated temperatures during the malting process.

\section{Fine-grind extract and VZ45}

Fine-grind extract and VZ45 revealed high positive correlations of above 58\%. The VZ45 measures lowtemperature extraction and characterises cytolytic and proteolytic activity of malt enzymes. Cytolytic and proteolytic enzymes are involved in the breakdown of cell wall and degradation of starch into fermentable sugars, which results in the development of malt extract. Fine-grind extract was most strongly influenced by the QTL QFge.S42-1H.b which explained $10.7 \%$ of the genetic variance. This QTL coincides with the major QTL for VZ45, QVZ45.S42-1H.a. The same locus on $1 \mathrm{H}$ also showed an effect on friability, protein content and viscosity in this study. At the same region on 1H, Collins et al. (2003) identified a QTL for hot water extract in the populations Sloop/Alexis. In addition, Marquez-Cedillo et al. (2000) mapped a QTL for malt extract to the long arm of $1 \mathrm{H}$ in the Harrington/ Morex population.

As 26 lines showed transgressive segregation for VZ45 as compared to the elite parent, it was surprising that no QTLs with favourable effects of the exotic allele were recorded. This could be due to epistatic interactions between elite and exotic germplasm. On the other hand, a number of marker*environment interactions with favourable effects of the exotic allele were detected (data not shown). Due to differences in magnitude of the effects and cross over interactions, these loci were not significant as a marker main effect. The major QTL for VZ45 mapped to the long arm of chromosome $5 \mathrm{H}$ (QVZ45.S42-5H.b) and coincides with a QTL for height in S42 (von Korff et al. 2006) and with QTLs for $\alpha$-amylase and diastatic power mapped in Dicktoo $\times$ Morex (Oziel et al. 1996) and Steptoe $\times$ Morex (Hayes et al. 1993).

\section{PRO}

In breeding for malting quality moderate protein levels are desirable. A sufficient protein quantity is necessary to provide starch-degrading enzymes, whereas high protein contents reduce malt extract. 
In this study, however, protein content showed a low negative correlation with enzyme activity. The amount of grain protein was thus no limiting factor for enzyme activity. Protein content showed a strong negative correlation with malt extract of $-77 \%$ and with friability of $-63 \%$. Although the model corrected for protein content, two QTLs were overlapping between PRO and FGE and two QTLs between PRO and FRI. At these QTLs, common between PRO, FGE and FRI, the exotic allele increased protein content and reduced fine-grind extract and friability. Attempts to describe the negative relationship between protein and malt extract have been reviewed by Tatham and Shewry (1995) who showed that different hordein groups had some relationship to malt extract or final beer quality. In this study, the QTL QPro.S42-1H.a mapped to bin 3 where also the Hor loci have been located. Variation at this locus may thus be explained by differences in the structural composition of the exotic and elite Hor alleles.

\section{Viscosity and friability}

The cytolytic parameters viscosity and friability showed a correlation of $-82 \%$ in S42. QTLs with opposing effects of the exotic allele for FRI and VIS coincided at $1 \mathrm{H}, 3 \mathrm{H}, 5 \mathrm{H}$ and $6 \mathrm{H}$. The locus at the centromeric region of chromosome $1 \mathrm{H}$ had the strongest effect on both traits, explaining 16.0\% (FRI) and $19.1 \%$ (VIS) of the genetic variance. As viscosity and friability are mainly affected by the breakdown of $\beta$-glucan and other cell wall polysaccharides, genes affecting $\beta$-glucan or $\beta$-glucanase activity may underlie the QTLs detected for viscosity and friability. Indeed, the strongest QTLs for viscosity and friability, QVis.S42-1H.a and QFri.S42-1H.a, coincided with QTLs for $\beta$-glucan and $\beta$-glucanase activity detected in the Steptoe/Morex population (Han et al. 1995). The exotic allele at the QTL on 3H, bin 10 improved friability and viscosity and had also a favourable effect on fine-grind extract. Thomas et al. (1996) detected QTLs for $\alpha$-amylase, diastatic power and grain protein at the same location in the cross Blenheim $\times$ E224/3. This locus maps also close to a gene for $\alpha$-amylase, amy $b$, which may be at the basis of these QTLs. QFri.S42-6H.a and QVis.s42$6 \mathrm{H}$.a map to the location of the Amyl locus, and the favourable effect of the exotic allele on these two parameters may be explained by improved $\alpha$-amylase activity at this locus. QFri.S42-6H.a and QVis.s42$6 \mathrm{H}$.a do also partially overlap with QTLs for yield, heading date and a minor QTL for brittleness (von Korff et al. 2006) and may reflect differences in grain maturity. As brittle spikes were not collected prior to harvest, the remaining grain may have been later maturing and thus affected malting quality.

\section{Conclusion}

In this study, transgressive S42 lines with improved performance were detected for four out of seven analysed malting parameters, despite the overall inferior impact of the ISR42-8 germplasm on malting quality. The highest numbers of transgressive lines were detected for the traits VZ45 (26 S42 lines) and $\alpha$-amylase (20 S42 lines). Exotic alleles with a favourable effect on malting quality were identified at 18 out of 48 QTLs. Favourable exotic QTL alleles were detected on the chromosomes $3 \mathrm{H}, 4 \mathrm{H}, 6 \mathrm{H}$ and 7H. For example, three favourable exotic QTL-alleles for $\alpha$-amylase and protein content each, and one favourable exotic QTL-allele for friability were identified on chromosome $4 \mathrm{H}$. In addition, on chromosome arm $6 \mathrm{HL}$ the exotic allele increased $\alpha$ amylase by $16.0 \%$, fermentability by $1.3 \%$, friability by $7.3 \%$ and reduced viscosity by $2.9 \%$. In future, the favourable effects of the exotic alleles will be verified in a second $\mathrm{AB}$-population derived from the same donor germplasm and in near-isogenic lines. Pure introgression lines are currently generated (von Korff et al. 2004). These will be used to verify and fine-map the malt QTLs and to introgress the exotic QTL alleles into adapted germplasm.

Acknowledgements We thank Dr. Eberhard Laubach (Nordsaat Saatzucht) and his team for conducting the field experiment at Gudow. We are greatly indebted to Dr. Lissy Kuntze (Nordsaat Saatzucht, Böhnshausen) for the analysis of malting parameters. The excellent technical assistance of Merle Noschinski, Carsten Golletz, and the team of the Dikopshof Research Station in Wesseling is appreciated. This work was funded by the German Plant Genome Research Initiative (GABI) of the Federal Ministry of Education and Research (BMBF, project 0312278A).

\section{References}

Ahokas H, Naskali L (1990a) Geographic variation of $\alpha$-amylase, $\beta$-amylase, $\beta$-glucanase, pullulanase and 
chitinase activity in germinating Hordeum spontaneum barley from Israel and Jordan. Genetica 82:73-78

Ahokas N, Naskali L (1990b) Variation of $\alpha$-amylase, $\beta$ amylase, $\beta$-glucanase, pullulanase, proteinase and chitinase activity in germinated samples of the wild progenitor of barley. J Inst Brew 96:27-31

Baek HJ, Beharav A, Nevo E (2003) Ecological-genomic diversity of microsatellites in wild barley, Hordeum spontaneum, populations in Jordan. Theor Appl Genet 106:397-410

Barr AR, Jefferies SP, Broughton S, Chalmers KJ, Kretschmer JM, Boyd WJR, Collins HM, Roumeliotis S, Logue SJ, Coventry SJ, Moody DB, Read BJ, Poulsen D, Lance RCM, Platz GJ, Park RF, Panozzo JF, Karakousis A, Lim P, Verbyla AP, Eckermann PJ (2003a) Mapping and QTL analysis of the barley population Alexis $\times$ Sloop. Aust J Agric Res 54:1117-1123

Barr AR, Karakousis A, Lance RCM, Logue SJ, Manning S, Chalmers KJ, Kretschmer JM, Boyd WJR, Collins HM, Roumeliotis S, Coventry SJ, Moody DB, Read BJ, Poulsen D, Li CD, Platz GJ, Inkerman PA, Panozzo JF, Cullis BR, Smith AB, Lim P, Langridge P (2003b) Mapping and QTL analysis of the barley population Chebec $\times$ Harrington. Aust J Agric Res 54:1125-1130

Benjamini J, Yekutieli B (2005) Quantitative trait loci analysis using the false discovery rate. Genetics 171:783-790

Collins HM, Panozzo JF, Logue SJ, Jefferies SP, Barr AR (2003) Mapping and validation of chromosome regions associated with high malt extract in barley (Hordeum vulgare L.). Aust J Agric Res 54:1223-1240

Coventry SJ, Collins HM, Barr AR, Jefferies SP, Chalmers KJ, Logue SJ, Langridge P (2003) Use of putative QTLs and structural genes in marker assisted selection for diastatic power in malting barley (Hordeum vulgare L.). Aust J Agric Res 54:1241-1250

Choi DW, Koag MC, Close TJ (2000) Map locations of barley Dhn genes determined by gene-specific PCR. Theor Appl Genet 101:350-354

Choi DW, Rodriguez EM, Close TJ (2002) Barley Cbf3 gene identification, expression pattern, and map location. Plant Physiol 129:1781-1787

Costa JM, Corey A, Hayes PM, Jobet C, Kleinhofs A, Kopisch-Obusch A, Kramer SF, Kudrna D, Li M, RieraLizarazu O, Sato K, Szucs P, Toojinda T, Vales MJ, Wolfe RI (2001) Molecular mapping of the Oregon Wolfe barleys: a phenotypically polymorphic doubledhaploid population. Theor Appl Genet 103:415-424

Crosatti C, Nevo E, Stanca AM, Cattivelli L (1996) Genetic analysis of the accumulation of COR14 proteins in wild (Hordeum spontaneum) and cultivated (Hordeum vulgare) barley. Theor Appl Genet 93:975-981

EBC, European Brewery Convention (2005) Analytica-EBC. Fachverlag Hans Carl, Nürnberg, Germany, ISBN: 3-41800759-7

Eglington JK, Langridge P, Everson EH (1998) Thermostability variation in alleles of barley $\beta$-amylase. J Cereal Sci 28:301-309

Erkkilä MJ, Leah R, Ahokas H, Cameron-Mills V (1998) Allele-dependent barley grain $\alpha$-amylase activity. Plant Physiol 117:679-685
Evans DE, Collins H, Eglinton J, Wilhelmson A (2005) Assessing the impact of the level of diastatic power enzymes and their thermostability on the hydrolysis of starch during wort production to predict malt fermentability. J Am Soc Brew Chem 63:185-198

Forster BP, Russell JR, Ellis RP, Handley LL, Robinson D, Hackett CA, Nevo E, Waugh R, Gordon DC, Keith R, Powell W (1997) Locating genotypes and gene for abiotic stress tolerance in barley: a strategy using maps, markers and the wild species. New Phytol 137:141-147

Fox GP, Panozzo JF, Li CD, Lance RCM, Inkerman PA, Henry RJ (2003) Molecular basis of barley quality. Aust J Agric Res 54:1081-1101

Gao W, Clancy JA, Han F, Jones BL, Budde A, Wesenberg DM, Kleinhofs A, Ullrich SE (2004) Fine mapping of a malting-quality QTL complex near the chromosome $4 \mathrm{H} \mathrm{S}$ telomere in barley. Theor Appl Genet 109:750-760

Grando S, Ceccarelli S (1995) Seminal root morphology and coleoptile length in wild (Hordeum vulgare ssp. spontaneum) and cultivated (Hordeum vulgare ssp. vulgare) barley. Euphytica 86:73-80

Han F, Ullrich SE, Chirat S, Menteur S, Jesting L, Sarrafi O, Hayes MP, Jones BL, Blake TK, Wessenberg D, Kleinhofs A, Kilian A (1995) Mapping of $\beta$-glucan content and $\beta$ glucanase activity loci in barley grain and malt. Theor Appl Genet 91:921-927

Han F, Romagosa I, Ullrich SE, Jones BL, Hayes PM, Wesenberg DM (1997) Molecular marker-assisted selection for malting quality traits in barley. Mol Breed 3:427-437

Han F, Clancy JA, Jones BL, Wesenberg DM, Kleinhofs A, Ullrich SE (2004) Dissection of a malting quality QTL region on chromosome $1(7 \mathrm{H})$ of barley. Mol Breed 14:339-347

Hayes PM, Liu BH, Knapp SJ, Chen F, Jones B, Blake T, Franckowiak J, Rasmusson D, Sorrells M, Ullrich SE, Wesenberg D, Kleinhofs A (1993) Quantitative trait locus effects and environmental interaction in a sample of North American barley germplasm. Theor Appl Genet 87:392401

Hayes PM, Costro A, Marquez-Cedillo L, Corey A, Henson CA, Jones BL, Kling J (2003) Genetic diversity for quantitatively inherited agronomic and malting quality traits. In: Von Bothmer R, Van Hintum T, Knupffer H, Sato K (eds) Diversity in barley (Hordeum vulgare), Elsevier Press, New York, pp 147-169

Karakousis A, Barr AR, Kretschmer JM, Manning S, Logue SJ, Roumeliotis S, Collins HM, Chalmers KJ, Li CD, Lance RCM, Langridge P (2003) Mapping and QTL analysis of the barley population Galleon $\times$ Haruna Nijo. Aust J Agric Res 54:1131-1135

Kleinhofs A, Graner A (2001) An integrated map of the barley genome. Kluwer Academic Publishers, Dordrecht, The Netherlands, pp 187-199

Laurie DA, Pratchett N, Bezant JH, Snape JW (1995) RFLP mapping of five major genes and eight quantitative trait loci controlling flowering time in a winter $\times$ spring barley (Hordeum vulgare L.) cross. Genome 38:575-585

Li JZ, Huang XQ, Heinrichs F, Ganal MW, Röder MS (2005) Analysis of QTLs for yield, yield components, and malting quality in a BC3-DH population of spring barley. Theor Appl Genet 110:356-363 
MEBAK, Mitteleuropäische Brautechnische Analysenkommission (1997) Methodensammlung der Mitteleuropäischen Analysenkommission. Band I, 3. Auflage: Rohstoffe-Wasser, Gerste, Rohfrucht, Malz, Hopfen und Hopfenprodukte, ISBN 3-9805814-0-3

Maestri E, Klueva N, Perrotta C, Gulli M, Nguyen HT, Marmiroli N (2002) Molecular genetics of heat tolerance and heat shock proteins in cereals. Plant Mol Biol 48:667-681

Marquez-Cedillo LA, Hayes PM, Jones BL, Kleinhofs A, Legge WG, Rossnagel BG, Sato K, Ullrich E, Wesenberg DM, The North American Barley (2000) QTL analysis of malting quality in barley based on the doubled-haploid progeny of two elite North American varieties representing different germplasm groups. Theor Appl Genet 101:173-184

Mather DE, Tinker NA, LaBerge DE, Edney M, Jones BL, Rossnagel BG, Legge WG, Briggs KG, Irvine RB, Falk DE, Kasha KJ (1997) Regions of the genome that affect grain and malt quality in a North American two-row barley cross. Crop Sci 37:544-554

Oziel A, Hayes P, Chen F, Jones B (1996) Application of quantitative trait locus mapping to the development of winter-habit barley. Plant Breed 115:43-51

Paris M, Jones MGK, Eglington JK (2002) Genotyping single nucleotide polymorphisms for selection of barley $\alpha$-amylase alleles. Plant Mol Biol Rep 20:149-159

Pillen K, Zacharias A, Léon J (2003) Advanced backcross QTL analysis in barley (Hordeum vulgare L.). Theor Appl Genet 107:340-352

Read BJ, Raman H, McMichael G, Chalmers KJ, Ablett GA, Platz GJ, Raman R, Genger RK, Boyd WJR, Li CD, Grime CR, Park RF, Wallwork H, Pragnell R, Lance RCM (2003) Mapping and QTL analysis of the barley population Sloop $\times$ Halcyon. Aust J Agric Res 54:11451153

SAS Institute (2003) The SAS system for Windows, release 9.1. SAS Institute, Cary, NC, USA

Tanksley SD, Nelson JC (1996) Advanced backcross QTL analysis: a method of the simultaneous discovery and transfer of valuable QTLs from unadapted germplasm into elite breeding lines. Theor Appl Genet 92:191-203

Tatham A, Shewry P (1995) The S-poor prolamins of wheat, barley and rye. J Cereal Sci 22:1-16

Thomas WTB, Powell W, Swanson JS, Ellis RP, Chalmers KJ, Barua UM, Jack P, Lea V, Forster BP, Waugh R, Smith DB (1996) Quantitative trait loci for germination and malting quality characters in a spring barley cross. Crop Sci 36:265-273

von Korff M, Wang H, Léon J, Pillen K (2004) Development of candidate introgression lines using an exotic barley accession (H. vulgare ssp. spontaneum) as donor. Theor Appl Genet 109:1736-1745

von Korff M, Wang H, Léon J, Pillen K (2005) Detection of resistance genes against powdery mildew, leaf rust and scald introgressed from wild barley $(H$. vulgare ssp. spontaneum). Theor Appl Genet 111:583-590

von Korff M, Wang H, Léon J, Pillen K (2006) AB-QTL analysis in spring barley: II. Detection of favourable exotic alleles for agronomic traits introgressed from wild barley (H. vulgare ssp. spontaneum). Theor Appl Genet 112:1221-1231

Zale JM, Clancy JA, Ullrich SE, Jones BL, Hayes PM (2000) The North American barley genome mapping project summary of barley malting QTLs mapped in various populations. Barley Genet Newsl 30:44 